International Journal of Educational Review

Volume 3 Issue 2 (2021) Page 191-207

ISSN 2685-709X (Online) 2685-905X (Print)

\title{
Improving the Image of Private Islamic Religious Colleges in the Kopertais Region XIII Jambi Through Public Relations Management
}

\author{
Iwan Aprianto ${ }^{1}$, Muntholib ${ }^{2}$, Risnita ${ }^{3}$ \\ ${ }^{1}$ Institut Agama Islam Nusantara Batanghari, ${ }^{2,3}$ Universitas Islam Negeri Sultan \\ Thaha Saifuddin Jambi \\ Corresponding Author E-mail: iwanaprianto@iainbatanghari.ac.id
}

Received 23 May 2021; Revised 30 May 2021; Accepted 10 June 2021

\begin{abstract}
The purpose of this research is to uncover and describe how public relations management might help improve the image of private Islamic religious universities in Kopertais area XIII Jambi. Through participant observation, this study employs a qualitative descriptive technique. The subjects of the study included the Head of the Private Islamic Religious College, Deputy Chair III for Student Affairs and Quality Assurance, and the administrative / staff section of the private Islamic religious college in Kopertais Region XIII Jambi. Observation, interviews, and documentation are all used to acquire data. Data analysis using the Miles and Huberman approach, which includes data reduction, data display, and verification or conclusion drawing. The results show that public relations management improves image by executing management functions, which are then carried out by various programs that are conducted and based on establishing values of trust, motivation, or public perception, as well as higher education program activities aimed at the target, the general population, as well as the special society.
\end{abstract}

Keywords: Management, Public Relations, Image 


\section{Introduction}

Public relations, also known as public relations, plays a vital part in socializing a college. At order to build a positive image in the college, managers must always be friendly. Furthermore, public relations cannot be isolated from management and systems that are organized and run according to their respective functions. -Everyone. Public relations are a management function that establishes and maintains a positive and helpful relationship between an organization and the general public, which influences the organization's success or failure (Cutlip, 2016). A well-executed public relations function is a truly effective weapon for enhancing, developing rules, organizational or corporate culture, a favorable environment, being sensitive to personnel who require a different approach, having to be inspired to enhance their performance, and so on (Rumanti, 2016).

Public relations are a branch of the art of human social behavior that is being developed in order to make it more focused and inseparable from management, with the management being able to provide an arrangement in communication toward human social behavior in order to achieve set goals. Public relations, or PR, is more than simply a relationship; it is a particular approach that ensures a company's reputation and popularity in the eyes of the public (Musi, 2020). According to Nurtjahjani and Trivena (2018), public relations efforts are simply communication activities. However, in contrast to other types of communication activities, communication activities in public relations have specific features, which are typical, according to the role, the nature of the organization in which the public relations are based and takes place, the human qualities involved, particularly the target audience, the variables -External variables that impact, and so on.

Public relations management in improving the image of private Islamic religious colleges in the Kopertais Region XIII Jambi environment, in accordance with the theme which is the subject of the writer in a study, there needs to be a managerial supervision so that the essence of public relations can actually improve the image of a university since there is a managerial supervision in the management of higher education

According to Sagala (in Saihudin, 2018), supervision, often known as managerial control is a management function in an organization. This function must be completed in every organization because the inability or neglect to conduct these duties will have a significant impact on the success of organizational goals. 
Communication is inextricably linked to public relations since it is the most significant aspect of human life. Communication may solve conflicts and explain the basis of truth, science, and clear and comprehensive information; if it is related with public relations, or better known as public relations, it can be argued that public relations is communication; nevertheless, it is important to note that not all communication is public relations.

The existence of public relations is fundamentally linked to the image of a learning institution. Public relations, on the one hand, as an image of the quality of educational institutions, and on the other hand, as a medium of communication between school institutions and school consumers, can thus be developed through the active participation of public relations management in generating a favorable image and image of an educational institution. Maskur (2018) defines formalized formalized formalized formalized formalized formalized formalized formalized formalized formal.

To socialize a university in the midst of society, strong communication is required. An individual will be able to speak Indonesian in a variety of ways in addition to the local language. In this setting, all administrators and stakeholders must be able to communicate effectively in order to project an image of a university that can socialize with the surrounding community. The public relations role, often known as public relations, is immensely powerful in boosting a university's image in the eyes of society.

According to Kruckeberg (2014), organizations and communities should ideally have a harmonic relationship. Conversely, if the organization does not have a good relationship with the community, the community is hesitant to provide its goals.

The role of public relations in establishing a favorable image of an institution cannot be separated from how to develop a good relationship between the institution and the surrounding environment; further, in public relations, it is highly demanded to develop internal and external contacts with the community so that the image obtained is capable of providing a positive response to the community. The stimulus is supplied and is capable of making the community optimal for the reactions between the two sides, particularly in the area of education, where one must truly maintain public relations in order to boost the image of higher education.

People in the educational administration system do activities and make decisions that are right according to the rules and right according to ethics. So that 
all educational administration functions have objective values and satisfy ethics that grow from subjective awareness in the form of attitudes that fulfill commitments based on integrity in humans behaving and having activities in the educational administration system (Sagala, 2013).

Referring to the preceding viewpoint, if it is related with public relations, it can be seen that in implementing public relations to improve the image of educational institutions, particularly universities, it must also comply with ethical norms and signs so that the function of any running system can be effective and efficient in supporting the image of a university in the midst of society.

Because public relations play a critical purpose in developing the image of an organization or institution, especially for institutions such as universities in implementing public relations in the form of communication between managerial institutions and the community or staff at the institution, public relations management is very basic in developing the public image of higher education. so that there is a friendship relationship that creates a nice picture. According to Nawawi (in Subroto, 2012), the purpose of public relations is to publicize work organization activities that need to be widely recognized by outsiders; these activities are carried out by disseminating information or supplying information to the outside community in order to build a good knowledge of their obligations. and the organization's functions, including operations that have been, are being, and will be carried out based on volume and workload.

According to Sari (2017), the scope of public relations in a company or organization includes two parts: 1) fostering internal relations, where public relations must be able to identify or recognize negative images in society before implementing policies organization, and 2) fostering external relations, where public relations strive to identify or recognize negative images in society before implementing policies organization.

According to Sari (2017), public relations have a scope in identifying all bad images that will befall the institution, as well as finding and cultivating a positive attitude in improving the public image of the institution that has been planned for the long term. In the short and long term, the author wishes to investigate more deeply the role of public relations management in improving the public image of private Islamic religious colleges, where in an all-digital era and the government's demands for universities to be accredited, how is the management of university public relations private universities are able to compete with state universities. 
Based on the findings of the grand tour, the researchers conclude that public relations management in improving the image of higher education includes carrying out activities that have direct contact with the community, developing short, medium, and long-term programs that are directly related to the community, improving services to students who study on campus, and increasing accredition. Based on a grand tour of three private Islamic religious colleges in Kopertais Region XIII Jambi, researchers will investigate several components in this study, including how the image of private Islamic religious colleges, particularly in Kopertais Region XIII Jambi, with the research title "Improving the Image of Private Islamic Religious Colleges in the Kopertais Region XIII Jambi Through Public Relations Management”.

\section{Methods}

This study employed a qualitative descriptive methodology based on participant observation to describe, describe, and investigate and describe public relations management in boosting the image of the Private Islamic Religious College in the Kopertais Region XIII Jambi area. According to Creswell (2018), researchers began their research by gathering as much information as possible from participants, then categorizing or thematically organizing this material in qualitative research as a technique. According to Moleong (2014), qualitative research has certain qualities that set it apart from other types of research.

This research was conducted at universities in Kopertais Region XIII Jambi. The locations or places that researchers have determined to conduct research in this study are STAI Ma'arif Jambi City, STAI An-nadwah Kuala Tungkal Tanjung Jabung Barat Regency, and STAI Syekh Maulana Qori (SMQ) Bangko Merangin Regency.

The subjects of the study included the Head of the Private Islamic Religious College, Deputy Chair III for Student Affairs and Quality Assurance, and the administrative/ staff section of the private Islamic religious college in Kopertais Region XIII Jambi.

In qualitative research, data gathering procedures rely primarily on the findings of observations, which are then supplemented with interview data and documentation gathered in the field. Data analysis in this study follows the Miles and Huberman flow data analysis paradigm, in which data analysis activities are carried out during research activities (during data collecting), and comprise of data reduction, data presentation, and verification or drawing conclusions. 


\section{Results and Discussion}

\section{1) STAI An-Nadwah Kuala Tungkal}

a. Public relations management has been unable to improve the image of Kopertais Region XIII Jambi's private Islamic religious universities

Based on the findings of field observations, researchers concluded that the community service activities done by lecturers were still insufficient in an effort to engage directly with the community. In an endeavor to promote the image of higher education, it cannot be separated from public relations or with the word public relations, which is a barrier at the STAI An-Nadwah Kuala Tungkal campus, aside from not maximizing community service activities carried out by lecturers, the role of alumni has not been maximized.

According to the findings of field researchers, an organization in the form of an Alumni Association had been formed, however the campus was not doing its best to mobilize the members of the STAI An-Nadwah Kuala Tungkal Alumni Association.

Public relations management has not been able to improve the image of the tertiary institution at STAI An-Nadwah Kuala Tungkal for a variety of reasons, one of which is that it has not maximally implemented the tridharma of higher education, particularly in the field of community service, so that people do not fully understand what programs are carried out by the college, and then the role of the alumni, ideally, they are very skewed.

Based on observations, interviews, and documentation of researchers at the STAI An-Nadwah Kuala Tunggal campus, public relations management initiatives have not been able to alter the image of private Islamic religious colleges because, First, public relations and higher education are not optimal in carrying out the tridharma of higher education, particularly in the field of devotion to community, and the two responsibilities of campus groups such as alumni association organizations have not contributed much to the institution's success.

The three accreditations of departments or study programs at STAI AnNadwah Kuala Tungkal have not all been accredited 'B,' thus there is a shortage of community enthusiasts to continue their studies at the college because the department or study program he is going to take has not been accredited, despite the fact that the community has begun to pay attention to accreditation in each study program. University. Because they are still manual, the four services to 
students have not been optimized in this digital era, and they are a little delayed in providing services to students.

Due to insufficient public relations with universities, the four problems mentioned above that are the cause of public relations management have not been able to improve the image of the higher education institution at STAI An-Nadwah Kuala Tungkal.

\section{b. Public Relations Management in Kopertais Region XIII Private Islamic Religious Colleges Jambi is a place in Indonesia}

Public relations management in private Islamic religious colleges in Jambi XIII's Kopertais area does not arise from the management role itself, namely planning, organizing, ordering, coordinating, and controlling. STAI An-Nadwah Kuala Tunggal surely performs the five management duties listed above in order to improve the university's image.

The researcher then made observations, seeing that the teaching staff or lecturers were less disciplined in performing community service, with some doing it and others not. According to the findings of interviews and observations of public relations management at the Private Islamic Religious College in the Kopertais Region XIII Jambi environment, particularly at STAI An-Nadwah Kuala Tungkal, it was carried out; nevertheless, researchers discovered that it was still less controlled and disciplined in carrying out tufoksi (main tasks and functions). There is still an excessive SKS burden on lecturers at STAI AnNadwah Kuala Tungkal.

Then, STAI An-Nadwah Kuala Tunggal's public relations management still lacks good communication management with alumni, despite the fact that alumni are extremely effective media in communicating the institution or STAI AnNadwah Kuala Tungkal to the larger community.

Public relations management at STAI An-Nadwah Kuala Tungkal is still oriented toward a management style that does not prioritize control and assessment, so that management functions do not align well with the outcomes of undisciplined public relations management to better communication with university users afterwards. The service is also focused on one individual exclusively in an effort to improve the college's image, thus it appears that public relations management only focuses on one person, thus that management can be referred to as pragmatism management. 


\section{c. Illustration of a Private Islamic Religious College in Kopertais Region XIII, Jambi}

The image of private Islamic religious colleges in Jambi province, particularly those under Kopertais Region XIII Jambi, is unquestionably competent, since nearly every city area in Jambi province has a private Islamic religious university under the auspices of the regional Kopertais. XIII Jambi. Only STIT (Sekolah Tinggi Ilmu Tarbiyah) and STAI (Sekolah Tinggi Agama Islam) have previously altered their status, and now private Islamic religious colleges under Kopertais area XIII Jambi have transformed or shifted status to IAI (Institut Agama Islam).

This demonstrates that private Islamic higher education institutions in Jambi province are becoming more prevalent and well-known in the larger community, particularly among Jambi residents. STAI An-Nadwah Kuala Tungkal is a private institution under the auspices of Kopertais area XIII Jambi that is in high demand by the community, as seen by the growing number of students that attend or study at STAI An-Nadwah Kuala Tungkal each year.

The public's perception of private Islamic religious colleges has improved as a result of the Minister of Religion of the Republic of Indonesia's Regulation Number: 33 of 2016 about academic degrees of religious colleges, in which academic degrees of colleges under the auspices of the Ministry of Religion are equated as Islamic Education Study Program. The title of the graduate of the Islamic Religious Education (PAI) study program (Bachelor of Education).

Based on interviews and field observations, researchers discovered that the image of private tertiary institutions under the auspices of Kopertais in the XIII Jambi region, particularly STAI An-Nadwah Kuala Tungkal, has improved, as evidenced by the community's strong desire to continue their education at these tertiary institutions. Aside from the bachelor's degree, accreditation is an important component of higher education's appeal in society; with strong accreditation, the university's image will indirectly improve.

\section{d. Public Relations Management to Improve the Image of Private Islamic Religious Colleges in Kopertais Region XIII Jambi}

Public relations management in improving the image of higher education has its own program and style. In an effort to improve the image of the university, STAI An-Nadwah Kuala Tungkal developed public relations management, which prioritizes academic services to students. 
According to observations and interviews, the public relations management used at STAI An-Nadwah Kuala Tungkal provides great service to students and campus visitors with the goal of boosting the university's public image in the midst of society. Then there is public relations management, which is applied to STAI An-Nadwah Kuala Tungkal, and time management, which is the management of lecture time at STAI An-Nadwah Kuala Tungkal. Students study from morning to noon, and there are also classes from noon to noon. There are lessons available from the afternoon through the evening, and students can select a time or class that best suits their needs.

Public relations management in developing the image of higher education at STAI An-Nadwah Kuala Tungkal by dividing lecture time, which is also part of managing community connections with universities to improve the college's image. Aside from that, the STAI An-Nadwah Kuala Tungkal campus is concerned with the production of alumni certificates provided by the campus.

\section{2) STAI Ma'arif Jambi}

a. The reputation of private Islamic religious universities in Kopertais Region XIII Jambi has not been improved by public relations management

According to the findings of observations and interviews with field researchers, the lack of social capital is also a barrier to public relations management in strengthening the image of the STAI Ma'arif university in Jambi City. Because the STAI Ma'arif college is relatively close to the surrounding district, the bulk of persons who continue their studies at STAI Ma'arif Jambi City are from nearby districts, particularly Muaro Jambi district.

Public relations management has not been able to improve the university's image, one of which is the accreditation element in the present study programs at STAI Ma'arif college, Jambi City, because accreditation is part of the institution's aikon to mingle with the community in an effort to improve the image of a university in the middle. Currently, in the perspective of the community, accreditation is a requirement for getting a job in government entities.

Researchers in the study field observed that STAI Ma'arif Jambi City's partnership with universities had been implemented, one of which was through organizing international seminars in which speakers from other campuses interacted with presenters at STAI Ma'arif Jambi. According to the findings of observations and interviews with researchers in the field of collaboration, one type 
of public relations management was applied to STAI Ma'arif Jambi City, but this management was unable to improve the image of STAI Ma'arif Jambi City since the MoU was not fully executed.

Because public relations is a public relationship that is strongly tied to improving the image of the university itself, public relations management should be able to improve the image of higher education; however, if it is not executed effectively, public relations management also does not function in an effort to improve the image of higher education, in carrying out Public relations management is inextricably linked to the management function, which consists of planning, organizing, ordering, coordinating, and controlling.

\section{b. Management of Public Relations at Private Islamic Religious Colleges in Kopertais Region XIII Jambi}

Public relations management at the Private Islamic Religious College in Kopertais Region XIII Jambi is well known among the people of Jambi province in general. STAI Ma'arif Jambi City is one of the universities under the aegis of the XIII Jambi region cooperative whose work is well known by the public, although there is public relations management at STAI Ma'arif Jambi City in an effort to improve the university's image.

Management applied to STAI Ma'arif Jambi City to improve the image of higher education is to develop regulations by assigning additional tasks to permanent lecturers, particularly to participate in socializing the STAI Ma'arif Jambi City campus to the community, with the goal of managing public relations in an effort to improve college image.

According to the findings of observations and interviews, researchers observed public relations management at STAI Ma'arif Jambi City ordering or giving instructions to lecturers to socialize STAI Ma'arif Jambi City to the surrounding area, which resulted in STAI Ma'arif's market share.

\section{c. Illustration of a Private Islamic Religious College in Kopertais Region XIII, Jambi}

The image of STAI Ma'arif college in Jambi City has already been acknowledged by the public, particularly the inhabitants of Jambi City, as evidenced by STAI Ma'arif Jambi City alumni who have been acknowledged or accepted as workers or employees in government agencies or private companies. Based on each alumni's scientific field and competence. 
Aside from that, STAI Ma'arif Jambi City collaborates with foreign parties to make this campus recognized internationally through the cooperation carried out, and the execution of this collaboration is completed by having an international seminar with seminar speakers from the campus. STAI Ma'arif Jambi City and the campus in partnership with STAI Ma'arif Jambi City.

Apart from that, with the collaboration carried out by STAI Ma'arif Jambi City with foreign parties, making this campus known internationally through the cooperation carried out, the implementation of this collaboration is realized by holding an international seminar where the seminar speakers are from the campus. STAI Ma'arif Jambi City and the campus in collaboration with STAI Ma'arif Jambi City.

Then the researchers made observations in the field, looked at documents of international seminars and/ or webinars held by STAI Ma'arif Jambi City, based on these observations, it was seen that STAI Ma'arif Jambi City carried out these national seminars or webinars by including lecturers and/ or officials. as a resource person and also as a moderator in this prestigious event or event.

According to the findings of observations and interviews on the image of STAI Ma'arif college, Jambi City has been very well-known by the public, particularly through international activities often carried out by universities, and thus the name STAI Ma'arif Jambi City has been booming internationally through the implementation of the cooperation or MoU carried out by STAI Ma'arif Jambi City.

\section{d. Improving the Image of Private Islamic Religious Colleges in Kopertais Region XIII Jambi Through Public Relations Management}

Boosting the image of higher education cannot be isolated from the regular and directed management applied to universities, particularly those linked to public relations management or what is known as public relations management, public relations management, the direct communication that the institution builds with the community. STAI Ma'arif Jambi City's public relations management comprises strengthening current regulations, rewarding lecturers, motivating lecturers to continue their studies at a higher level, changing organizational culture, making the work environment favorable, and providing incentives to increase employee performance.

Developing rules is one of the public relations management initiatives implemented by the academic community of STAI Ma'arif Jambi City in an effort to improve the image of higher education, a management breakthrough such as 
this is a strategic management that has not been widely held by a leader, private campuses if they do not dare to create breakthroughs. New discoveries and innovations in the organization's wheels, the heavier the organization is to go forward, the important factor is not to breach patal regulations, such as providing diplomas where students never interact with the learning process, this is a problem for the academics.

Jambi City, in addition to implementing STAI Ma'arif guidelines, offers reward programs for lecturers in an effort to foster healthy management in the STAI Ma'arif Jambi City environment. The researchers then looked for information about the type of award granted by STAI Ma'arif Jambi City.

The problem is how public relations management at the Private Islamic Religious College at STAI Ma'arif Jambi City has not been able to improve the image of the Private Islamic Religious College at STAI Ma'arif Jambi City then what is the image of the Private Islamic Religious College STAI Ma'arif Jambi City and the final issue is how to improve the image of the Private Islamic Religious College at STAI Ma'arif Jambi City through public relations management.

Although STAI Ma'arif Jambi City is located in the center of the province, it is able to compete with large public and private campuses, as evidenced by the many alumni from STAI Ma'arif Jambi City. In accordance with the developing rules of STAI Ma'arif Jambi City higher education, higher education continues to improve to meet the demands in higher education management, such as increasing the certification of study programs and universities to improve educational quality.

\section{3) STAI Syekh Maulana Qori Bangko}

\section{a. Public Relations Management Cannot Improve the Image of Private} Islamic Religious Higher Education in Kopertais Region XIII Jambi

In this case, the STAI Syekh Maulana Qori Bangko college is a private Islamic religious college under the auspices of Kopertais region XIII Jambi, Syekh Maulana Qori Bangko college is a university Islamic religion in Merangin Regency, the existence of Syekh Maulana Qori Bangko higher education is very strategic.

Based on their observations in the field, the researchers discovered that the community seemed to measure the level of education at STAI Syekh Maulana 
Qori Bangko, and they were confident that with this quality, they wished to continue their studies at STAI Syekh Maulana Qori Bangko.

According to the findings of the above observations and interviews, one of the reasons why public relations management has not been able to change the image of STAI Syekh Maulana Qori Bangko higher education is that the quality of education is inseparable from the production of graduating alumni provided by STAI Syekh Maulana Qori Bangko then accreditation. Higher education must be addressed as well in order to improve the image of STAI Syekh Maulana Qori Bangko higher education.

Apart from the quality of the accreditation education of STAI study programs, Syekh Maulana Qori Bangko is also one of the reasons why public relations management has been unable to improve the image of higher education. Of course, socializing the tertiary institution cannot be divorced from presenting the advantages offered by the college; if the college lacks many strengths or power, the management of public relations or public relations in communicating is somewhat impeded.

According to the observations and interviews conducted by researchers, the accreditation of study programs at STAI Syekh Maulana Qori Bangko is one of the reasons why public relations management has not been able to improve the image of the university, public relations, particularly at STAI Syekh Maulana Qori Bangko College, is a community relationship in which the relationship This community is inextricably linked to how to communicate the strengths and limitations of STAI Syekh Maulana Qori Bangko higher education to the general public in order to improve the college's image.

This means that public relations management at STAI Syekh Maulana Qori Bangko is still constrained by accreditation of study programs, so that management in communicating tertiary institutions to the community is constrained, in this example, public relations refers to how the effort to offer information on the STAI Syekh Maulana Qori Bangko campus is conveyed to the public and how the public recognised what was conveyed by the administration of the STAI Syekh Maulana Qori Bangko higher education regarding the selling value or image of the STAI Syekh Maulana Qori Bangko college.

\section{b. Management of Public Relations at Private Islamic Religious Colleges in Kopertais Region XIII Jambi}


The STAI Syekh Maulana Qori Bangko's public relations management followed the regular procedures that had been set ahead of time, but success is inextricably linked to the limits that force every step to effectively manage higher education.

Collaborations or Memorandums of Understanding (MOUs) that have been established by STAI Syekh Maulana Qori Bangko with universities both inside and outside the tertiary institution have been widely implemented, but their execution has not been fully completed, examples of collaboration with international universities such as student exchanges, difficulties in the field are the first students from outside to continue The study at STAI Syekh Maulana Qori Bangko about the unsupported facilities owned by STAI Syekh Maulana Qori Bangko, then our students who we want to send are bound by costs, that is, the implementation of the MoU collaboration cannot run optimally; however, if this can run optimally and well, it will, of course, improve the image of the university, particularly STAI Syekh Maulana Qori Bangko, as the community will see the ability and quality of STAI Syekh Maulana Qori Bangko.

Researchers' observations in the field, researchers saw and found documents of cooperation or MoU carried out by the management of STAI Syekh Maulana Qori Bangko cooperation or $\mathrm{MoU}$ carried out with domestic and foreign universities, cooperation or MoU with foreign campuses covering campuses located in the Malysia state and the Sudanese state, while in the country, cooperation or an MoU is carried out with the IAIN Batu Sangkar Padang campus, IAIN Lampung.

\section{c. Illustration of a Private Islamic Religious College in Kopertais Region XIII, Jambi}

In an organization, an image is a belief or someone's impression when looking at something or a place of actual fact; the picture is abstract. As a result, the community will judge the image of private Islamic religious colleges in the Kopertais area of the XIII Jambi district, particularly STAI Syekh Maulana Qori, based on the reality on the ground.

According to the findings of observations and interviews with field researchers, the image of the STAI Syekh Maulana Qori Bangko college is fairly good, because it is capable of fostering a positive perception of the community, so that the STAI Syekh Maulana Qori Bangko college is no longer underestimated by the community. 
Because many alumni from the STAI Syekh Maulana Qori Bangko college have been accepted in the sphere of work, the image of the STAI Syekh Maulana Qori Bangko college is undoubtedly by the community at this time. Observations of researchers in the research field revealed that the image of higher education was already positive in the eyes of the community, in line with the ability of STAI Syekh Maulana Qori Bangko students or alumni to compete for jobs.

One of the image formation is cognition (building individual belief), which we strive to improve in order to persuade every individual in society that the STAI Syekh Maulana Qori Bangko college will later be implemented in public relations management or the relationship between STAI Syekh Maulana Qori Bangko higher education, especially building individual community beliefs may be done not only with scientific excellence, but also with other facilities that can help the university's reputation.

\section{d. Improving the Image of Private Islamic Religious Universities in the Kopertais Region XIII Jambi via Public Relations Management}

According to research findings, one of the best programs of the STAI alumni of Syekh Maulana Qori Bangko was to participate in socialization activities, then on Islamic holidays and/ or other beneficial activities required to carry the name of the STAI Syekh Maulana Qori Bangko college.

Because alumni are very media, public relations management at STAI Syekh Maulana Qori Bangko higher education comprises creating intense relationship with alumni, then tracking alumni who have gotten employment such as being permanent employees and those who have worked in government agencies. beneficial in promoting higher education's image.

Public relations management at STAI Syekh Maulana Qori Bangko higher education through utilizing media in the form of mass media and other online media, in line with the current development of the young/ millennial community is actively using online social media, even though media such as this is a media that has been passed down from generation to generation at the STAI Syekh Maulana Qori Bangko colleg Online media, such as Facebook media, are examples of effective media in communicating activities carried out at the STAI Syekh Maulana Qori Bangko college so that the entire community is aware of what activities are carried out.

According to observations and interviews conducted by researchers in the field, the public relations management built at the STAI Syekh Maulana Qori 
Bangko college by building closeness with the local government to get support and support, so that the relationship between the two parties supports each other, particularly from the programs that are run. This implies that in creating and building the image of the STAI Syekh Maulana Qori Bangko college, communication with the community in the area is very important, so that the influence of good relations makes STAI Syekh Maulana Qori Bangko college have a positive image in the eyes of the community.

Based on the findings of observations and interviews with field researchers, it is possible to conclude that public relations management is part of an effective program to be applied to universities. In addition to the demands of national tertiary accreditation and the implementation of the tridharma of higher education, the guided village program has an impact on improving the image of the university. The assisted village can also create a positive perception in the eyes of the community; the community will judge that the existence of the STAI Syekh Maulana Qori Bangko higher education is felt by its existence, not only in terms of vision, but also in terms of spirit, as evidenced by the various activities carried out in the assisted village program.

\section{Conclusion}

Based on data analysis from the field discussion and research findings, it can be concluded that public relations management in improving the image of private Islamic religious colleges in the Kopertais Region XIII Jambi environment by implementing management functions is then carried out by various programs that are run and based on building value

\section{Acknowledgement}

We would like to express our special thanks and gratitude to Institut Agama Islam Nusantara Batanghari, Rector UIN STS Jambi, Director of Graduate Program UIN STS Jambi and Study Program of Islamic Educational Management UIN STS Jambi who gave us the support to do this wonderful project. This project was funded independent. Secondly, we would also like to thank our friends in Islamic Educational Management who helped us a lot in finalizing this project within the limited time frame. 


\section{References}

Creswell, J. W. (2018). Penelitian Kualitatif \& Deasin Riset Edisi 3 [Qualitative Research \& Research Design Edition 3]. Yogyakarta: Pustaka Pelajar.

Cutlip, S. M. (2016). Efektif Public Relations edisi ke 9 [Effective Public Relations 9th edition]. Jakarta: Prenada Media Group.

Kruckeberg, D. (2014). The Future of PR Educations: Some Recommendations. Journal Public Relations Review, Vol. 24, No. 2, pp. 235-248.

Maskur. (2018). Manajemen Humas Pendidikan Islam: Teori dan Aplikasi [Islamic Education Public Relations Management: Theory and Application]. Yogyakarta: CV Budi Utama.

Moleong, L. J. (2014). Metode Penelitian Kualitatif [Qualitative Research Methods]. Bandung: Rosda.

Musi, S. (2020). Krisis Public Relations Teori dan Praktek [Public Relations Crisis Theory and Practice]. Jawa Timur: Qiara Media.

Nurtjahjani, F., \& Trivena, S. M. (2018). Public Relations Citra \& Praktek. Malang: Polinema Press.

Rumanti, M. A. (2016). Dasar-Dasar Public Relations Teori dan Praktik [Fundamentals of Public Relations Theory and Practice]. Jakarta: PT Grasindo.

Sagala, S. (2013). Etika dan Moralitas Pendidikan Peluang dan Tantangan [Ethics and Morality of Educational Opportunities and Challenges]. Jakarta: Kencana Pernadamedia Group.

Saihudin. (2018). Manajemen Institusi Pendidikan [Management of Educational Institutions]. Ponorogo: Uwais Inspirasi Indonesia.

Sari, A. A. (2017). Dasar-dasar Public Relations Teori dan Praktik [Fundamentals of Public Relations Theory and Practice]. Yogyakarta: CV Budi Utama.

Subroto, S. (2012). Hubungan Sekolah dengan Masyarakat [School Public Relation]. Jakarta: Rineka Cipta. 